DOI 10.18551/rjoas.2019-06.32

\title{
HAKAWAK CULTURE IN IMPROVING CULTURAL SOCIAL RESILIENCE AT WEOE VILLAGE
}

\author{
Nahak Romualdus Juniarto* \\ Interdisciplinary Study Program, Master Program of National Security, \\ University of Brawijaya, Malang, Indonesia
}

\author{
Afandhi Aminudin, Wike, Lecturers \\ Interdisciplinary Study Program, University of Brawijaya, Malang, Indonesia \\ *E-mail: waldusnahak@gmail.com
}

\begin{abstract}
The objectives of this study are 1) to explore new forms of hakawak culture in the present (hakawak malae); 2) to analyze the contributions that can be found in the Hakawak Malae culture in enhancing socio-cultural resilience in Weoe Village; 3) develop strategies for the culture of hakawak in facing the challenges of the times in the future. This study uses a qualitative method. The results of the study showed that the hakawak culture experienced transformation in three forms, namely farmer groups, money gathering, and cooperatives. Although transformed in three completely new forms, the enthusiasm in it is still a true spirit of hakawak. Hakawak also contributes to people's lives. The presence of hakawak malae actually strengthens the existing hakawak tradition. Therefore, in order not to fall into the old hakawak romanticism, an understanding of hakawak must always be in accordance with the period in which humans live. If this period is the 21 st century, then the meaning of hakawak must be in accordance with this 21 st century.
\end{abstract}

\section{KEY WORDS}

Culture, Hakawak, New Form, Socio-cultural resilience.

The discourse about mutual cooperation is not new to the people of Indonesia. In Indonesia, every culture has the term to express the mutual cooperation. In the Tetun tribal community, Malaka Regency, East Nusa Tenggara Province (NTT), mutual cooperation is known as hakawak. The concept of hakawak is known in all contexts of life together.

Along with the development of the times, globalization was born which comes with a double face. On the one hand, it presents many new hopes for a better life. The development of Science and Technology is a positive thing presented by globalization (Huda, 2019; Singla et al., 2019). It cannot be denied that on the other hand, without realizing it, it actually gives a bad hope for human life. This becomes evident as can be found in social life, for example life is increasingly individualistic, gloomy moral and ethical values in shared life, loss of native culture of a region or country, erosion of cultural values, decreasing sense of nationalism and patriotism, and loss of kinship and mutual cooperation (Suneki, 2012). In addition, globalization can also produce opinions that can develop wildly and can affect the behavior of individuals, communities, and countries (Irfan, 2017; Tsui et al., 2018; Jamali \& Karam, 2018; De Mooij, 2019; Singla et al., 2019; Huda, 2019).

In line with that, it cannot be denied that the hakawak culture is gradually being eroded by the flow of globalization that is increasingly heating up. The concept of hakawak was finally engulfed by the vortex of the times.

Faced with globalization which continues to develop science and technology, questions that are quite crucial arise in the meaning of hakawak along with the times, will it fade or even disappear? In addition, will this activity still be feasible in the midst of a society that has changed considering that for the Weoe Village community in particular and Indonesia in general, hakawak is not only talking about behavior, but also acting as moral values? Furthermore, considering the paradigms in society are beginning to change, will hakawak 
also be able to change form in other forms, when human life shifts according to the development of science and technology?

Hakawak is a milestone in life in community life. This culture must be revived, although not in its initial form, so that the community can work hand in hand so that the bonum commune (common good) is achieved. Hakawak, which was once understood as mutual cooperation in the garden, had to be moved to its meaning and found a new form for the world today. If some time ago, hakawak occurred in the context of development, this time hakawak must be transformed to be able to break through the limits of meaning so that it can be lived in the midst of society. If some time ago, hakawak was considered as a fairly constructive thing in community life, nowadays the hakawak culture must be revitalized in a new form so that it can build a community life towards a better direction. In other words, the culture of hakawak for this age, must be re-explored, re-seen, and revived in a new form.

\section{METHODS OF RESEARCH}

The type of research used in this study is qualitative research. The use of this qualitative research method departs from the curiosity of the researchers to explore the problems related to the hakawak culture in Weoe Village. According to Bodgan and Taylor (1975: 5, in Idrus, 2009), Qualitative methods are research procedures that produce descriptive data in the form of written or oral words from people and observable behavior. Thus, through qualitative research, a detailed description of the situation or process under study will be carried out (Idrus, 2009).

The qualitative research approach used by researchers to study the hakawak culture in Weoe Village so that it can improve social cultural resilience in Weoe Village is a phenomenological and ethnographic approach.

The sources of data and information to be obtained in this study are very important so that they need to be accurately determined. The goal is that the information obtained really comes from sources that have relevance, closeness, and authority with this research. Thus the information obtained is accurate, reliable information, so that it can be used as valid data for research on this hakawak culture.

Primary data, is data obtained directly from the object under study. Secondary data is obtained through literature studies from books, the results of previous studies such as undergraduate theses, theses, dissertations, journals and the internet which of course relate to this hakawak culture. In this study, researchers used qualitative data analysis based on data analysis models revealed by Creswell (Creswell, 2012: 274-284).

\section{RESULTS AND DISCUSSION}

Hakawak is also known as "Karian Serikat" (United Work). Literally, karian serikat can be understood as the work of an association or work in an association. Of course this means that the work is carried out by many people, carried out jointly, hand held together "all by all" to reach the bonum commune.

Hakawak or karian serikat actually occur in groups. Work carried out using energy, coupled with hard work, is very unlikely to be done alone, whether it is working in the garden or building a new roof house. Therefore, it is a necessity if the work is carried out jointly. If it is associated with groups and the spirit of hakawak that was previously lived by the community, then it is not an exaggeration to say that the hakawak performed by the community are the forerunner to the formation of groups that are developing. Groups such as money gathering, cooperatives, and farmer groups are manifestations of hakawak that have long been lived by the community.

The flourishing of several groups is enough to give its own color to the life of the Weoe Village community. If a straight thread is drawn, then will find the spirit of hakawak found in the groups that are flourishing. In the context of Weoe Village, hakawak transformed into three new forms, namely Farmers Group, Money Gathering and Cooperatives. This transformation of hakawak culture can also be called modern hakawak. Even though it is 
transformed in a new form, the spirit of hakawak that underlies it remains a true spirit of hakawak.

Discourse on socio-culture means discourse on the two main aspects of human life, namely the social aspect in which humans for the sake of their survival must cooperate with fellow human beings, and aspects of culture which are the whole way of life, whose manifestations appear in behavior and institutionalized behavioral outcomes. Social culture in a broad sense covers all aspects of life. while in a narrow sense, social culture is placed as an aspect of national life in addition to ideology, politics, economics, and defense security (Verdery, 1991; Ball, 1993; Lemhanas: 1995: 73; Katzenstein, 1996; Inglehart, 2018; BergSchlosse, 2019; Ponsioen, 2019; De Mooij, 2019; Lo et al., 2019; Elander \& Gustavsson, 2019). Human beings for the sake of their survival must establish cooperation with fellow humans. If it is connected with the hakawak malae that occurs, then a meeting point will be found. To carry out their lives, the community cooperates with each other. This collaboration is evident in farmer groups, money gathering and cooperatives. In other words, human beings always have connections with others. This connectedness presupposes that "I" must get out of him to be able to meet " the other I". The meeting between "I" and " the other I" forms into "us". In "us" this is the manifestation of cooperation being realized.

The manifestation of this collaboration is in line with one of the factors that influence socio-cultural resilience, namely socio-economic conditions (Lemhanas, 1995: 78). To be able to fulfill its economic life, the community conducts hakawak. Hakawak is carried out such as money gathering and cooperatives. In addition, this manifestation of socio-economic conditions also appears in farmer groups. Some of the crop yield from the farmer groups are sold. Money from the sale of the crop yield is used to meet the needs of the farmer groups.

The presence of hakawak malae reinforces the existing culture. The spirit that underlies farmer groups, money gathering and cooperatives is hakawak. This is in line with the culture lived by the community, namely hakawak. Thus, hakawak malae affirms the existence of the hakawak culture. In addition to strengthening the existing culture, the presence of hakawak malae can be read in the context of revitalizing culture that has begun to be rarely done. As previously stated, hakawak is rarely done. With the presence of hakawak malae, the hakawak culture which is rarely carried out can be revived. Thus, it can be seen that hakawak malae also contributes to tradition, which is one of the factors of sociocultural resilience.

On the other hand, one of the dimension of socio-cultural resilience is transformative capacities (Keck and Patric in Lestari, 2016: 141; Fastenrath et al., 2019; McOmber et al., 2019; Wilson \& Wilson, 2019; Santo \& Moragues, 2019; Lemos et al., 2019; Hostettler et al., 2019; Wardani \& Kusumasari, 2019; Bakker et al., 2019). If a straight thread is pulled, then there will be a very close relationship. The starting point of the development of hakawak malae is the hakawak that has been lived by the community for a long time. Hakawak also has the capacity to transform. The transformation of this hakawak culture became evident in farmer groups, money gathering and cooperatives. Thus the flourishing of the hakawak malae in Weoe Village provides strong evidence that social cultural resilience also increases.

Actually hakawak is carried out together. This indicates that hakawak can only occur if humans gather into a single unit, gathering to join hands together. This is certainly formed because there is a human awareness that humans are always connected with others, always needing others. In order hakawak can continue to live facing the flow of globalization, then the strategy offered is about the meaning of hakawak, that hakawak must be interpreted in accordance with the times. Because this period is the 21st century, the understanding of hakawak must be in accordance with the current context. In the sense that hakawak must be understood in the context of the rapid development of science and technology, it must be able to be understood as modern hakawak. To actualize this, what needs to be done is to borrow knowledge and technology that has developed to be able to join hands together. A simple example, when there was an earthquake and tsunami in Palu and Donggala, there were some Indonesian people who used social media such as Facebook, Instagram and WhatsApp to raise funds. This is proof that the development of science and technology can be borrowed for hakawak. 


\section{DISCUSSION OF RESULTS}

Traditional wisdom is all forms of knowledge and beliefs, understanding or insight as well as customs or ethics that guide human behavior in life within an ecological community. All this wisdom is lived out, practiced, taught, and passed down from one generation to another which at the same time forms the pattern of everyday human behavior, both to fellow human beings and to the unseen nature. Thus local wisdom here not only concerns the knowledge and understanding of indigenous people about humans and how good relations between humans (Sillitoe, 2019; Sabinot \& Lescureux, 2019; Shawoo et al., 2019; PageReeves et al., 2019), but also concerning knowledge, understanding, and customs about humans, nature, and how is the relationship between all residents and ecological communities this must be built (Keraf, 2002: 289).

To be able to understand hakawak malae, the fundamental thing that must be understood is the starting point of the hakawak malae. The discourse on the starting point of hakawak malae is a necessity to re-explore the hakawak that occur in the community, especially the Weoe Village community. To arrive at this, it must be understood that hakawak is traditional wisdom. Therefore, the effort to re-explore this great thing is simply and solely by returning to traditional society, especially the Weoe Village community.

As previously stated, hakawak in the lives of the Weoe village community takes place in two forms, namely hakawak ema mane (hakawak performed by men) and hakawak ema feto (hakawak performed by women). Hakawak ema mane usually occurs in gardens, while hakawak ema feto includes hakawak hiri kabas (spun yarn) and soru tais (woven fabric). Besides that, hakawak also occurs in various spheres of human life such as party or death activities, building new houses, and so on.

Hakawak in the Weoe Village community can be read as traditional group solidarity. In this context, community solidarity to help others. Even though it is carried out in a small (local) scope, but the community always draws good from the hakawak that is done. This means that when the hakawak are carried out, the goals to be achieved are realized. $\mathrm{n}$ addition, in general public understanding, something can only be done if done together. Just say the construction of a new house, because it requires a lot of raw materials and energy, then cooperation is a necessity. Thus in the hakawak community, individualist attitude is a mistake. Because for the hakawak community, the common good is a shared task. In other words, the true hakawak man is in the community, because the persona of hakawak people is fully fulfilled when manifested in society. The solidarity of this traditional group also found its shape for the present. In Weoe Village, the solidarity of this traditional group is manifested in the form of farmer groups, money gathering and cooperatives. Although in different forms, solidarity within these groups remains the same as the solidarity that occurs in society.

In traditional groups there is a dimension of local knowledge (Mitchell, 2003 dalam Humannira, 2016: 30). Local knowledge is understood as the ability of the community to adapt to their environment. The environment cannot be understood in human relations with nature alone, but wider than that. Adaptation to the environment can also be understood in human relations with their social life. In this local knowledge, there is knowledge about hakawak. From the knowledge of the hakawak, humans adapt to their environment. Adaptation to the environment has a very close relationship with meeting human needs. And to fulfill their needs, humans do hakawak. For example, when a time when humans need cloth to cover their bodies, women do hakawak hiri kabas and soru tais so that all family members can wear cloth. Human knowledge, especially about hakawak, is not something that is massive. But on the contrary, knowledge of hakawak develops over time, as previously explained. For example, once the community only understood hakawak in the sense of hakawak in the garden, hiri kabas, soru tais, and so on, now that knowledge is developing. The community now understands that hakawak also occurs in farmer groups, money gathering and cooperatives. Thus, it can be said that local knowledge about hakawak also developed.

From the explanation above, it can be seen that hakawak is traditional wisdom. In this traditional wisdom found local group solidarity, whose manifestation is real in hakawak. In 
addition, there is a growing traditional knowledge. Community understanding of hakawak also developed. This understanding of hakawak is not only about local group solidarity but is broader than that. This solidarity with the true spirit of hakawak is manifested in institutionalized groups such as farmer groups and cooperatives, as well as in noninstitutional groups namely money gathering. By seeing the hakawak that was previously carried out by the people and drawn a thread by the solidarity of this new group, it is true that it is said that hakawak gets a new face. Farmer groups, money gathering and cooperatives are clear evidence of this new face of hakawak. hakawak malae. In other words, because hakawak is traditional wisdom, it can be said that traditional wisdom has a new face. Therefore, it is no exaggeration to say that hakawak is always new local wisdom.

\section{CONCLUSION AND RECOMMENDATIONS}

Hakawak always develops from time to time. The development of hakawak from time to time affirms that the hakawak soul always lives in society. In Weoe Village, it was found that hakawak transformed in a new form. The transformation of hakawak can be found in three forms, namely farmer groups, money gathering, and cooperatives.

The presence of Hakawak Malae gave its own contribution to the socio-cultural resilience of the Weoe Village community. Indeed, human beings for the sake of their survival must establish cooperation with fellow humans. If it is connected with the hakawak malae that occurs, then a meeting point will be found. To carry out their lives, the community cooperates with each other. This collaboration is evident in farmer groups, money gathering and cooperatives. The manifestation of cooperation is evident in the contributions of hakawak malae. One form of contribution from hakawak malae to the lives of the Weoe Village community is solidarity. The presence of hakawak malae actually strengthens this solidarity. In addition to self-help, education is one form of contribution from hakawak malae to the people of Weoe Village. In hakawak, education grows thriving. In socio-cultural resilience, one of the factors that contributes to socio-cultural resilience is education. Because education from hakawak malae thrives, it cannot be denied that social cultural resilience also grows. Thus, it can be seen that education from hakawak malae provides its own contribution in enhancing social and cultural resilience in Weoe Village. In hakawak malae, the value of self-help is strengthened. In addition, the embodiment of this cooperation is in line with one of the factors that influence socio-cultural resilience, namely socioeconomic conditions. To be able to fulfill its economic life, the community conducts hakawak.

Keontjaraningrat divide hakawak into two types, namely mutual help hakawak and mutual aid community work.

First, mutual cooperation for mutual help. The system of mutual help (which is also called mutual cooperation) is indeed not always given willingly and sincerely, but there are several levels of willingness, depending on the type of activities in social life.. Thus it can be distinguished between: (1) mutual help in agricultural activities, (2) mutual help in activities around the household, (3) mutual help in preparing for the party and ceremony, and (4) mutual help during the disaster. Second, mutual aid community work. In addition to the habit of helping each other among a small community in various social lives, there are activities that are jointly worked out, called "mutual cooperation". Such activities are carried out by a large number of community members to work together to complete a certain project that is considered beneficial for the public interest, namely community work activities or community service. There are two types of mutual aid community work, namely (1) cooperate in projects initiated by the community members themselves, and (2) collaborating on projects ordered by the Village Head. The projects initiated by the community members themselves of course the benefits are truly felt, because of that they are done with sincerity and full of enthusiasm. On the other hand, projects that are ordered from above, often they do not understand the true benefits, and are perceived as obligations that they cannot avoid except by representing them to others (by rewarding money). To get a positive response from community members, the Government or the Village Head must indeed be able to convince the villagers of the 
benefits of a project for the entire village so that they are willing to work enthusiastically (Koentjaraningrat, 2005: 152-153).

Reflecting on what was expressed by Koentjaraningrat, it was necessary to explore every hakawak malae. In general, hakawak malae that occur in Weoe Village can be categorized mutual help hakawak. This is because the hakawak that occur always assume that everyone must join hands together to do something. Hakawak is used as a "calling power" when hakawak human suffer. For example, when hakawak people need money to fulfill their needs, the community carries out money gathering hakawak.

Mutual help Hakawak then divided into mutual help in farming activities, mutual help in activities around the household, mutual help in preparing parties and ceremonies, and mutual help during the disaster. Mutual help in agricultural activities manifested in the form of farmer groups. Because farmer groups occur within the scope of agriculture, it is certain that the mutual help that happened was certainly in agricultural activities. In other words, farmer groups as hakawak malae are the mutual help hakawak in agricultural activities.

Money gathering as hakawak malae included in the mutual help around household activities and mutual help during the disaster. Mutual help in activities around the household is evident when the money earned from the money gathering is used to meet the household needs of each member of the money gathering hakawak. In addition, money gathering is also included in the mutual help when the disaster occurs because there is solidarity in the money gathering provided by each member of the money-gathering to members who experience grief..

Cooperatives can be categorized into mutual help around the household and mutual help when disaster occurs. Cooperatives are a place where humans can help each other. Money collected by members can be used by other members to meet their household needs. This mutual help can be said as undirectly mutual help, because the money collected is still accommodated by the cooperative, then it is only forwarded to other members in need. Even so, the mutual help still materialize. This mutual help relationship can be read as follows: from members, accommodated by cooperatives, and return to members. The cooperative is also included in the mutual help during the disaster. The solidarity of grievances given to members' heirs is clear evidence of mutual help during this disaster.

Research Suggestions. Hakawak is an Indonesian culture. Therefore this very great culture needs to be maintained and preserved so that it still exists and can be used to build a society. In this paper, some suggestions will be given, as follows:

- Need for further research on the transformation of the culture of hakawak. This needs to be done because the research related to the transformation of the Hakawak culture is still very little. This means that with the continued research on the transformation of hakawak, the Indonesian culture of hakawak is increasingly enriched. It is also intended that the understanding of hakawak be expanded.

- $\quad$ Need for efforts to "institutionalize" the hakawak. "Institutionalizing" hakawak can be understood as follows: First, by reflecting on what was revealed by Soekarno that the ekasila of pancasila is hakawak (mutual cooperation), and further elaborated by Driyarkara as the philosophical (life view) of the Indonesian nation, it is necessary to instill this philosophical in in Indonesian people. The point is that of course it is not excessive if this great philosophy is taught on every level of education, starting from elementary to university level, as a special subject.

Second, because hakawak is a characteristic of the Indonesian nation, the Government must also contribute to maintaining the existence of hakawak by forming a special institution on hakawak.

- One of the factors that caused the start of hakawak is rarely carried out by Indonesian people in general is politics. Therefore, it is necessary to carry out reconciliation efforts from those who won the election, for example the Village Head to the President.

- Recently Indonesian people have easily formed in groups through the development of social media such as Facebook, Instagram and WhatsApp and other social media. It is no exaggeration if through social media like this, hakawak groups are formed. 


\section{REFERENCES}

1. Bakker, Y. W., de Koning, J., \& van Tatenhove, J. 2019. Resilience and social capital: The engagement of fisheries communities in marine spatial planning. Marine Policy, 99, 132-139.

2. Ball, D. 1993. Strategic culture in the Asia-Pacific region. Security Studies, 3(1), 44-74.

3. Berg-Schlosser, D. 2019. Comparative Methods in Transformation Research: Political Culture. The Handbook of Political, Social, and Economic Transformation, 231.

4. Creswell, John W., 2012. Research Design: Pendekatan Kualitatif, Kuantitatif, and Mixed. Yogyakarta: Pustaka Pelajar.

5. De Mooij, M. 2019. Consumer behavior and culture: Consequences for global marketing and advertising. SAGE Publications Limited.

6. De Mooij, M. 2019. Consumer behavior and culture: Consequences for global marketing and advertising. SAGE Publications Limited.

7. Elander, I., \& Gustavsson, E. 2019. From policy community to issue networks: Implementing social sustainability in a Swedish urban development programme. Environment and Planning C: Politics and Space, 2399654418820077.

8. Fastenrath, S., Coenen, L., \& Davidson, K. 2019. Urban Resilience in Action: the Resilient Melbourne Strategy as Transformative Urban Innovation Policy?. Sustainability, 11(3), 693.

9. Hostettler, S., Jöhr, A., Montes, C., \& D’Acunzi, A. 2019. Community-based landslide risk reduction: a review of a Red Cross soil bioengineering for resilience program in Honduras. Landslides, 1-13.

10. Huda, M. 2019. Empowering application strategy in the technology adoption: insights from professional and ethical engagement. Journal of Science and Technology Policy Management, 10(1), 172-192.

11. Humannira, Raden Regia, 2016. "Proses Internalisasi Nilai Kearifan Lokal Masyarakat Banten Pada Mahasiswa yang Tergabung dalam Organisasi Kedaerahan (Studi Deskriptif di Organisasi Kedaerahan Perhimpunan Mahasiswa Banten Bandung)", Institutional Repositories \& Scientific Journals (September) E Journal on-line. Melalui http://repository.unpas.ac.id/13175/5/BAB\%202.pdf. [21/08/2018].

12. Idrus, Muhammad, 2009. Metode Penelitian IImu Sosial: Pendekatan Kualitatif and Kuantitatif, Edisi Kedua. Jakarta: Erlangga.

13. Inglehart, R. 2018. Culture shift in advanced industrial society. Princeton University Press.

14. Irfan, Maulana, 2016. "Crowdfunding sebagai Pemaknaan Energi Gotong Royong Terbarukan", SHARE: Social Work Journal (Juni) E Journal on-line. Melalui http://fisip.unpad.ac.id/jurnal/index.php/share/article/view/67. [13/08/2018].

15. 2017. "Metamorfosis Gotong Royong Dalam Pandangan Konstruksi Sosial", Prosiding Penelitian \& Pengabdian Kepada Masyarakat (Januari) E Journal on-line. Melalui http://jurnal.unpad.ac.id/prosiding/article/view/14204/6868. [4/09/2018].

16. Jamali, D., \& Karam, C. 2018. Corporate social responsibility in developing countries as an emerging field of study. International Journal of Management Reviews, 20(1), 32-61.

17. Katzenstein, P. J. (Ed.). 1996. The culture of national security: Norms and identity in world politics. Columbia University Press.

18. Katzenstein, P. J. 1998. Cultural norms and national security: Police and military in postwar Japan. Cornell University Press.

19. Keraf, Sonny, 2002. Etika Lingkungan. Jakarta: Kompas.

20. Koentjaraningrat, 2005. Pengantar Antropologi: Pokok-pokok Etnografi II. Jakarta: Rineka Cipta.

21. Lemhanas, 1995. Ketahanan Nasional. Jakarta.

22. Lemos, M. F., Saback, L., Rego, L. F., Antunes, M. C., \& Lopes, R. A. (2020). PUC-Rio Socio-environmental Agenda: New Steps Towards Sustainability in the University. In Universities as Living Labs for Sustainable Development (pp. 733-746). Springer, Cham. 
23. Lo, K. W., Ip, A. K., Lau, C. K., Wong, W. S., Ngai, G., \& Chan, S. C. 2019. Integrating Majors and Non-majors in an International Engineering Service-Learning Programme: Course Design, Student Assessments and Learning Outcomes. In Service-Learning for Youth Leadership (pp. 145-163). Springer, Singapore.

24. McOmber, C., Audia, C., \& Crowley, F. 2019. Building resilience by challenging social norms: integrating a transformative approach within the BRACED consortia. Disasters, 43, S271-S294.

25. Page-Reeves, J., Marin, A., Moffett, M., DeerInWater, K., \& Medin, D. 2019. Wayfinding as a concept for understanding success among Native Americans in STEM:"learning how to map through life". Cultural Studies of Science Education, 1-21

26. Ponsioen, J. A. 2019. The analysis of social change reconsidered: A sociological study (Vol. 4). Walter de Gruyter GmbH \& Co KG.

27. Sabinot, C., \& Lescureux, N. 2019. Local Ecological Knowledge and the Viability of the Relationships with the Environment. In Coviability of Social and Ecological Systems: Reconnecting Mankind to the Biosphere in an Era of Global Change (pp. 211-222). Springer, Cham.

28. Santo, R., \& Moragues-Faus, A. 2019. Towards a trans-local food governance: Exploring the transformative capacity of food policy assemblages in the US and UK. Geoforum, 98, 75-87.

29. Shawoo, Z., \& Thornton, T. F. 2019. The UN local communities and Indigenous peoples' platform: A traditional ecological knowledge-based evaluation. Wiley Interdisciplinary Reviews: Climate Change, e00575.

30. Sillitoe, P. 2019. Investigating local knowledge: New directions, new approaches. Routledge.

31. Singla, A., Sethi, A. P. S., \& Ahuja, I. S. 2018. A study of transitions between technology push and demand pull strategies for accomplishing sustainable development in manufacturing industries. World Journal of Science, Technology and Sustainable Development, 15(4), 302-312.

32. Suneki, Sri, 2012. "Dampak Globalisasi Terhadap Eksistensi Budaya Daerah." Civis (Januari) E Journal on-line. $\quad$ Melalui http://journal.upgris.ac.id/index.php/civis/article/view/603. [7/08/2018].

33. Tsui, A. S., Enderle, G., \& Jiang, K. 2018. Income inequality in the United States: Reflections on the role of corporations.

34. Verdery, K. 1991. National ideology under socialism: identity and cultural politics in Ceausescu's Romania (Vol. 7). Univ of California Press.

35. Wardani, A. P., \& Kusumasari, B. 2019. Socio-Cultural Dynamics of Resilience Building: Lesson Learned from Sleman, Indonesia. JKAP (Jurnal Kebijakan and Administrasi Publik), 23(1), 63-76.

36. Wilson, G. A., \& Wilson, O. J. 2019. Assessing the resilience of human systems: a critical evaluation of universal and contextual resilience variables. Resilience, 7(2), 126-148. 